\title{
The Spiritual Evolution of Cabeza de Vaca in Shipwrecks
}

\author{
Ali Shehzad Zaidi ${ }^{1}$
}

This article examines the refashioning of the self that took place during the eight-year journey of Alvar Núñez Cabeza de Vaca and his companions through North America. These four survivors of a Spanish expedition adopted shamanic practices that endeared them to indigenous communities residing in the southwestern region of North America. Through the alchemy of suffering, Cabeza de Vaca underwent a spiritual transformation that heralded a new American identity. His plea for justice for the indigenous peoples of the Americas makes him a historical figure worthy of remembrance and commemoration. [Article copies available for a fee from The Transformative Studies Institute. E-mail address: journal@transformativestudies.org Website: http://www.transformativestudies.org (C2014 by The Transformative Studies Institute. All rights reserved.]

KEYWORDS: Alvar Núñez Cabeza de Vaca, Florida, identity, Spanish explorers, Pánfilo de Nárvaez

Alvar Núñez Cabeza de Vaca (1507-59) served as the king's representative and treasurer for an expedition that explored Florida under a mandate from the Spanish Crown. In his report to the Spanish king Carlos V, first published in 1542 as La relación (The Narrative) and again in 1555 as Naufragios (Shipwrecks), by which title it subsequently became known, Cabeza de Vaca describes the arduous eight-year odyssey (1528-36) from Florida through northern Mexico which culminated in his spiritual transformation.

Before joining the Florida expedition led by Pánfilo de Narváez, Cabeza de Vaca had been a Spanish soldier who had fought several

\footnotetext{
${ }^{1}$ Ali Shehzad Zaidi, Ph.D., is Associate Professor at the State University of New York. Address correspondence to: Ali Shehzad Zaidi; e-mail: azaidi@transformativestudies.org.
} 